\title{
Synthesis, Swelling Properties and Evaluation of Genotoxicity of Hydrogels Based on (Meth)acrylates and Itaconic Acid
}

\author{
Dijana Takić Miladinov ${ }^{a *}$, Simonida Tomićc ${ }^{b}$,Sanja Stojanovićc,d, Jelena Najdanovićc,d, Jovanka
}

Filipovićb, Miroslav Trajanoviće, Stevo Najman ${ }^{c, d}$

\author{
${ }^{a}$ Department of Biology and Ecology, Faculty of Sciences and Mathematics, University of Niš, Niš, Serbia \\ ${ }^{b}$ Department of Organic Chemical Technology, Faculty of Technology and Metallurgy, University of \\ Belgrade, Belgrade, Serbia \\ 'Department for Cell and Tissue Engineering, Faculty of Medicine, University of Niš, Niš, Serbia \\ ${ }^{d}$ Department of Biology and Human Genetics, Faculty of Medicine, University of Niš, Nišs, Serbia \\ ${ }^{e}$ Laboratory for Intelligent Production Systems, Faculty of Mechanical Engineering, University of Niš, \\ Niš, Serbia
}

Received: March 15, 2016; Revised: June 8, 2016; Accepted: July 25, 2016

\begin{abstract}
In this study we prepared hydrogels based on 2-hydroxyethyl methacrylate (HEMA): PHEMA homopolymer and two terpolymers of HEMA, itaconic acid (IA) and two poly(alkylene glycol) (meth) acrylates (PAGM): poly(ethylene glycol) ${ }_{6}$ acrylate (P(HEMA/IA/PAGM1)) and poly(propylene glycol) methacrylate (P(HEMA/IA/PAGM2)). Hydrogels were synthesized by gamma-irradiated radical polymerization and subjected to swelling measurements and genotoxicity evaluation. Swelling studies confirmed that these hydrogels deserve consideration as biomaterials due to their ability to swell in phosphate buffer but maintaining physical integrity for a prolonged contact time after equilibrium state has been reached. Comet assay showed certain genotoxic effect following cell exposure to extracts of hydrogels, which was dependent on the concentration of extracts, chemical composition of hydrogels and the degree of crosslinking. The influence of concentration on genotoxicity was the most pronounced. The synthesis of these novel HEMA-based hydrogels should be optimized so as to reduce their toxicity and enable the use in clinical practice.
\end{abstract}

Keywords: HEMA-based hydrogels, itaconic acid, swelling, genotoxicity, Comet assay

\section{Introduction}

Hydrogels are three-dimensional crosslinked polymer networks that exhibit the ability to swell and retain a significant amount of water or biological fluids within their structure ${ }^{1,2}$. In the swollen state, hydrogels are soft and rubbery, resembling natural living tissue more than any other class of synthetic biomaterials ${ }^{3-6}$. Therefore, hydrogels have found widespread applications in medicine as wound dressings ${ }^{6,7}$, contact lenses ${ }^{8}$ and artificial skin'; in tissue engineering for reparation and regeneration of organs and tissues such as bones ${ }^{10,11}$ and cartilages ${ }^{12}$, and in pharmacy as controlled drug delivery systems $\mathrm{s}^{6,13-15}$.

Hydrogels based on 2-hydroxyethyl methacrylate (HEMA) are very commonly studied for use as biomaterials in different applications because of theirs excellent physicochemical properties ${ }^{16}$. HEMA is generally prepared in the form of copolymeric hydrogels with ionic or more hydrophilic monomers ${ }^{17}$. Copolymers of HEMA with methacrylic ${ }^{18}$, acrylic ${ }^{19}$ and itaconic acid $^{20}$, as $\mathrm{pH}$ sensitive components, have been reported previously as stimuli-responsive hydrogels for use in drug delivery systems ${ }^{9}$. Although many HEMA-based hydrogels are generally considered to be non-toxic and have been used in biomedical applications ${ }^{21-23}$, the information

* e-mail: takicdijana@gmail.com on their safety is still incomplete. HEMA, as (meth)acrylate monomer, is capable to induce various adverse effects at cellular level, such as oxidative stress, cell cycle disturbance and apoptosis ${ }^{24-27}$. Table 1 shows the results of different in vitro studies which have demonstrated that HEMA is a potent mediator of DNA damage, at concentrations ranging from micromolar to millimolar. On the other side, only few studies tested the genotoxic potential of polymerized hydrogels, and the results were controversial.

Most of the problems associated with hydrogels regarding toxicity are unreacted compounds such as monomers, oligomers, initiators, stabilizers, inhibitors, emulsifiers and crosslinkers used in hydrogel synthesis. The process of hydrogel polymerization is almost always incomplete, resulting in the presence of unreacted compounds, which in turn can cause cytotoxic and genotoxic effects leading to irreversible disturbance of basic cellular functions ${ }^{13}$. Moreover, Samuelsen et al. ${ }^{36}$ suggested that, if released at low concentrations for a prolonged period of time, HEMA could reduce the cellular proliferation rate and lead to apoptosis probably due to DNA damage. Since genotoxicity can limit or completely disable the use of materials in clinical practice, it is very important to evaluate potential genotoxicity of any novel material intended for implantation or long term exposure. 
Table 1: Genotoxic potential of HEMA monomer and extracts of polymerized hydrogels assessed in various cell types by employing different genotoxicity tests.

\begin{tabular}{|c|c|c|c|c|}
\hline Monomer & Cell line & $\begin{array}{c}\text { Genotoxicity test } \\
\text { (monomer concentration) }\end{array}$ & Result & Reference \\
\hline \multirow{7}{*}{ HEMA } & $\begin{array}{l}\text { V79 Chinese hamster } \\
\text { lung fibroblasts }\end{array}$ & $\begin{array}{c}\text { Micronucleus } \\
\text { Comet assay }(1-18 \mathrm{mM})\end{array}$ & $\begin{array}{l}\text { Genotoxic effect in a dose- } \\
\text { dependent manner. }\end{array}$ & Lee et al. $2006^{28}$ \\
\hline & $\begin{array}{l}\text { V79 Chinese hamster } \\
\text { lung fibroblasts }\end{array}$ & Micronucleus (2-8 mM) & $\begin{array}{l}\text { Genotoxic effect in a dose- } \\
\text { dependent manner. }\end{array}$ & Schweikl et al. $2007^{29}$ \\
\hline & $\begin{array}{c}\text { Human peripheral blood } \\
\text { lymphocytes }\end{array}$ & Comet assay & $\begin{array}{l}\text { Mild enhancement of DNA } \\
\text { migration. }\end{array}$ & Kleinsasser et al. $2004^{30}$ \\
\hline & $\begin{array}{c}\text { Human samples of } \\
\text { salivary glands } \\
\text { Human peripheral blood } \\
\text { lymphocytes }\end{array}$ & Comet assay & $\begin{array}{l}\text { Significant DNA migration in } \\
\text { both cell types. }\end{array}$ & Kleinsasser et al. $2006^{31}$ \\
\hline & $\begin{array}{l}\text { Human peripheral blood } \\
\text { lymphocytes } \\
\text { A549 lung-tumour cells }\end{array}$ & Comet assay $(0-10 \mathrm{mM})$ & $\begin{array}{l}\text { Increased DNA damage in a } \\
\text { dose-dependent manner }\end{array}$ & Pawlowska et al. $2010^{32}$ \\
\hline & $\begin{array}{l}\text { Human peripheral blood } \\
\text { lymphocytes }\end{array}$ & $\begin{array}{c}\text { Comet assay } \\
\text { Micronucleus } \\
\text { Chromosome aberration } \\
\text { (CA) } \\
\text { Sister chromatid exchange } \\
\text { (SCE) } \\
(10 \mu \mathrm{M}-1 \mathrm{mM})\end{array}$ & $\begin{array}{l}\text { Genotoxic effect was } \\
\text { measurable in the comet assay } \\
\text { at } 1 \mathrm{mM} \text { of HEMA, but not } \\
\text { in the micronucleus test. A } \\
\text { significant dose-dependent } \\
\text { increase in the frequency } \\
\text { of CAs and SCEs could be } \\
\text { demonstrated in all tested } \\
\text { concentrations. }\end{array}$ & Ginzkey et al. $2015^{33}$ \\
\hline & $\begin{array}{l}\text { Human gingival } \\
\text { fibroblasts }\end{array}$ & Comet assay $(1-10 \mathrm{mM})$ & $\begin{array}{l}\text { Increased tail DNA in a dose- } \\
\text { dependent manner. }\end{array}$ & $\begin{array}{l}\text { Szczepanska et al. } \\
2012^{34}\end{array}$ \\
\hline IA & \multicolumn{4}{|c|}{ N/A } \\
\hline PAGM & \multicolumn{4}{|c|}{ N/A } \\
\hline Hydrogel & Cell line & $\begin{array}{l}\text { Genotoxicity test (extract } \\
\text { concentration) }\end{array}$ & Result & Reference \\
\hline NVP-AA ${ }^{a}$ & HepG2 & $\begin{array}{c}\text { Comet assay }(0.25-25 \\
\mathrm{mg} / \mathrm{ml})\end{array}$ & $\begin{array}{l}\text { Four to six fold increase in } \\
\text { DNA breaks. }\end{array}$ & Devine et al. $2006^{5}$ \\
\hline NVP-AA & $\begin{array}{l}\text { HepG2 } \\
\text { HaCaT }\end{array}$ & $\begin{array}{l}\text { Comet assay } \\
\text { Ames assay }\end{array}$ & Genocompatible & Kirf et al. $2010^{23}$ \\
\hline ALPF-HEMA $^{b}$ & L929 fibroblasts & Comet assay & Genocompatible & Finosh et al. $2014^{35}$ \\
\hline
\end{tabular}

${ }^{\mathrm{a}} \mathrm{N}$-vinyl-2-pyrrolidone/acrylic acid ${ }^{\mathrm{b}}$ Alginate-polypropylene fumarate/2-hydroxyethyl methacrylate

Over the past decade, Comet assay was developed as a rapid, simple, and sensitive technique for analyzing and quantifying DNA damage in individual cells $\mathrm{s}^{37,38}$. The Comet assay, also called single cell gel electrophoresis (SCGE), combines DNA gel electrophoresis with fluorescence microscopy in order to visualize migration of DNA strands from individual agarose-embedded cells $\mathrm{s}^{39}$. The resulting image resembles a "comet" with a distinct head consisting of intact DNA, and a tail which contains damaged or broken pieces of DNA. The amount of DNA liberated from the head of the comet during electrophoresis depends on genotoxic potential of tested compound ${ }^{37}$. Over time this method has been improved and today it is suitable for detection of DNA damage caused by double and single strand breaks, alkali labile sites, DNA crosslinking with DNA or protein and oxidative base damage. The advantages of Comet assay, relative to the other genotoxicity tests, include its high sensitivity for detecting low levels of both single and double stranded breaks in damaged DNA, small number of cells per sample, flexibility, low cost and ease of application ${ }^{40,41}$. Comet assay is increasingly used to test genotoxicity of hydrogels' extracts ${ }^{42}$ and other biomaterials ${ }^{13,30}$.

In our previous investigation we reported the radiationinduced synthesis of copolymeric hydrogels composed of 2-hydroxyethyl methacrylate (HEMA), itaconic acid (IA) and different poly(alkylene glycol) (meth)acrylates (PAGM) ${ }^{43}$. The PAGM components and itaconic acid were used to improve the hydrophilicity of PHEMA. Itaconic acid, as a ionic component, imparts $\mathrm{pH}$ sensitivity and influences the swelling and mechanical properties of hydrogels ${ }^{20}$. PHEMA and P(HEMA/IA/PAGM) hydrogels were characterized by Fourier transform infrared (FT-IR) spectroscopy, scanning electron microscopy (SEM) and thermogravimetric (TG) analysis. These analyses confirmed that they have an adequate 
chemical structure, porosity and thermal properties to be used as multifunctional hydrogels in biomedical applications, while in vitro citotoxicity test showed that none of the tested hydrogels were cytotoxic ${ }^{43}$.

The aim of the present study was to further characterize these novel HEMA-based hydrogels through evaluation of their swelling properties and genotoxic potential in vitro. The examined hydrogels were prepared in our laboratory by gamma-irradiated free radical polymerization and included: PHEMA, poly(2-hydroxyethyl methacrylate/itaconic acid/ poly(ethylene glycol) ${ }_{6}$ acrylate (P(HEMA/IA/PAGM1)) and poly(2-hydroxyethyl methacrylate/itaconic acid/poly(propylene glycol $)_{5}$ methacrylate (P(HEMA/IA/PAGM2)). To the best of our knowledge, these are the first studies referring to the genotoxic potential of hydrogels composed of above mentioned components, evaluated by Comet assay.

\section{Materials and Methods}

\subsection{Chemicals}

2-Hydroxyethyl methacrylate (HEMA), itaconic acid (IA) (both from Sigma-Aldrich, St. Louis, MO, USA), poly(alkylene glycol) (meth)acrylates: poly(ethylene glycol) acrylate (PAGM1) and poly(propylene glycol) ${ }_{5}$ methacrylate (PAGM2) (both from Laporte Chemicals, Luton, UK) were used as components for hydrogel preparation. Dulbecco's Modified Eagle Medium (DMEM), fetal bovine serum (FBS), stable glutamine, antibiotic-antimycotic solution, Trypsin-EDTA solution were purchased from Biological Industries (Kibbutz Beit-Haemek, Israel). Low melting point agarose and ethidium bromide (EtBr) were obtained from SERVA (Heidelberg, Germany) while regular agarose was obtained from Applied Biosystems (Foster city, CA, USA). Trypan blue dye, disodium EDTA, Tris and Triton X-100 were obtained from Sigma-Aldrich, St. Louis, MO, USA.

\subsection{Preparation of hydrogels}

The PHEMA and P(HEMA/IA/PAGM) hydrogels were prepared by gamma-irradiated free radical polymerization. The feed composition for each sample is listed in Table 2. According to the PAGM component samples were designated as P(HEMA/IA/PAGM1) and P(HEMA/IA/PAGM2). The same conditions were used to prepare the PHEMA hydrogel. The reaction mixture was degassed prior to polymerization and placed between two glass plates sealed with a PVC spacer $(2 \mathrm{~mm}$ thick). The reaction solution was irradiated in a ${ }^{60} \mathrm{Co}$ radiation source, under ambient conditions, at a dose rate of $0.5 \mathrm{kGy} / \mathrm{h}$, to absorbed dose of $25 \mathrm{kGy}$. After the reaction, the hydrogels were cut into discs and immersed in water for one week. Water was changed daily and collected. After 7 days, the collected water was concentrated to a smaller volume by evaporation and was used for determination of unreacted monomers. The amount of unreacted IA was determined by titration of extract against $\mathrm{NaOH}(0.05 \mathrm{~mol} / \mathrm{L})$ to phenolphthalein end point. On the other hand, the amount of unreacted HEMA and PAGM components was determined using UV spectroscopy ${ }^{43}$.

In all cases, the processes indicate that the conversion during polymerization/crosslinking reaction was high as demonstrated in Table 2.

\subsection{Swelling study}

Dynamic swelling measurements were performed in phosphate buffer at $\mathrm{pH} 7.4$ and temperature of $37^{\circ} \mathrm{C}$. Swollen gels were removed from the swelling medium at regular intervals, dried superficially with filter paper, weighed and placed in the same bath until constant weight was reached. The amount of fluid absorbed was monitored gravimetrically. The equilibrium degree of swelling $\left(q_{e}\right)$ was calculated as follows:

$$
q_{e}=\left(m_{e}-m_{o}\right) / m_{o}
$$

where $m_{e}$ is the weight of swollen hydrogel at equilibrium and $m_{o}$ is the weight of xerogel ${ }^{44,45}$. All swelling experiments were performed in triplicate.

The most important parameters characterizing a hydrogel network structure are the molecular weight between crosslinks $\left(\bar{M}_{c}\right)$, and the effective crosslinking density $\left(v_{e}\right)$. Caykara et al. ${ }^{46}$ described the molecular weight of the polymer chain between two neighboring crosslinks for ionic polymer networks by following relation:

$$
\begin{aligned}
& \frac{V_{1} X^{2} \phi_{2, s}^{2}}{4 I \bar{V}_{r}^{2}}\left(\frac{2 K_{a 1} K_{a 2}+10^{-p H} K_{a 1}}{2\left(10^{-p H}\right)^{2}+10^{-p H} K_{a 1}+K_{a 1} K_{a 2}}\right)^{2}= \\
& {\left[\ln \left(1-\phi_{2, s}\right)+\phi_{2, s}+\chi \phi_{2, s}^{2}\right]+\left(\frac{V_{1} \rho}{\bar{M}_{c}}\right) \phi_{2, r}^{2 / 3} \phi_{2, s}^{1 / 3}}
\end{aligned}
$$

where $K_{a 1}$ and $K_{a 2}$ are the first and second dissociation constants of a diprotic acid, $X$ is the weight fraction of ionisable polymer in the system, $I$ is ionic strength of the swelling medium, $\varphi_{2, S}$ is the polymer volume fraction in the swollen gel, $\varphi_{2, r}$ is the polymer volume fraction in the relaxed state, $V_{l}$ is the molar volume of water, $\rho$ is the polymer density, $\bar{V}_{r}$ is the average molar volume of polymer repeating units, and $\chi$ is the Flory polymer-solvent interaction parameter. Polymer volume fraction in the relaxed state $\left(\varphi_{2, r}\right)$ is determined according to the following formula:

$$
\left(\phi_{2, r}\right)=V_{d} / V_{r}
$$

where $\mathrm{V}_{\mathrm{d}}$ is volume of the polymer sample in dry state and $\mathrm{V}_{\mathrm{r}}$ is the volume of the polymer sample in relaxed state, immediately after synthesis. The volumes were calculated by measuring dimensions of hydrogels discs. The effective crosslinking density $\left(v_{e}\right)$ was calculated using the relation:

$$
v_{e}=\rho / \bar{M}_{c}
$$


Table 2: Feed compositions for P(HEMA/IA/PAGM) and PHEMA hydrogels.

\begin{tabular}{lccc}
\hline Component & P(HEMA/IA/PAGM1) & P(HEMA/IA/PAGM2) & PHEMA \\
\hline HEMA (mol\%) & 70 & 70 & 00 \\
PAGM 1 and 2 (mol\%) & 28 & 28 & 0 \\
IA (mol\%) & 2 & 2 & 10 \\
HEMA+IA+PAGM (wt\%) & 10 & 10 & 45 \\
Demineralized water (wt $\%)$ & 45 & 45 & 45 \\
Ethyl alcohol (wt\%) & 45 & 45 & 99 \\
Conversion (wt $\%)$ & 97.5 & 98.1 & 0 \\
\hline
\end{tabular}

\subsection{Preparation of hydrogels extracts}

Individual hydrogel discs were weighed $(0.2 \mathrm{~g}$ in total) and immersed in $5 \mathrm{ml}$ of complete DMEM (DMEM supplemented with $10 \%$ fetal bovine serum, antimycoticantibiotic solution and $2 \mathrm{mM}$ stable glutamine). Extraction of hydrogels was performed under sterile conditions in a water bath at $37{ }^{\circ} \mathrm{C}$ during 3 days. Extracts were then discarded and diluted with complete DMEM to give final concentrations of $10 \%$ and $50 \%$.

\subsection{Cell culture}

Genotoxic potential of hydrogels' extracts was tested using HeLa cell line (ATCC, Manassas, USA). Cells were grown in complete DMEM at $37^{\circ} \mathrm{C}$ in humidified atmosphere containing $5 \% \mathrm{CO}_{2}$. Medium was replaced every 2-3 days. After reaching approximately $70 \%$ confluence, cells were detached by using Trypsin-EDTA solution, centrifuged at $4{ }^{\circ} \mathrm{C}$ for $10 \mathrm{~min}$ at $1000 \mathrm{rpm}$, washed and appropriate cell density was set up by using Trypan Blue Dye.

\subsection{Treatment of cells}

HeLa cells were seeded in 12-well culture plate at a density of $3 \times 10^{4}$ cells per $\mathrm{ml}$. After 24 hours medium was replaced with extracts of hydrogels in concentrations of $10 \%$ and $50 \%$. Incubation of cells with extracts was continued for the next 24 hours. In parallel, the control cells were treated with $200 \mu \mathrm{M} \mathrm{H}_{2} \mathrm{O}_{2}$ for $15 \mathrm{~min}$ as positive control. Negative control were cells incubated only with complete DMEM (untreated cells). All samples, as well as controls were examined in triplicate.

\subsection{Comet assay}

Comet assay was performed according to procedure described by Dhawan et al. ${ }^{47}$ with some modifications. Following treatment, hydrogels' extracts and control media were removed and cell viability was determined as quickly as possible by using Trypan Blue Dye Exclusion Method to avoid false positive responses due to cytotoxicity. Subsequently, $100 \mu 1$ of the cell suspension was mixed with low-melting point agarose $(0.75 \% \mathrm{wt})$, and $50 \mu \mathrm{l}$ cell-aliquots were spread on slides precoated with normal-melting point agarose ( $1 \%$ wt). The slides were immersed into cold, freshly made lysis solution $(2.5 \mathrm{M} \mathrm{NaCl}, 100 \mathrm{mM}$ disodium EDTA, $10 \mathrm{mM}$ Tris, $1 \%$ Triton X-100; pH 10). Lysis of cells was performed in dark and cold room $\left(5^{\circ} \mathrm{C}\right)$ for 2 hours. Following alkaline unwinding for $40 \mathrm{~min}$ by immersion into cold electrophoresis buffer ( $300 \mathrm{mM} \mathrm{NaOH}, 1 \mathrm{mM}$ EDTA; $\mathrm{pH} \geq 13$ ), the slides were subjected to electrophoresis at $30 \mathrm{~V}$ and $300 \mathrm{~mA}$ for $40 \mathrm{~min}$. Slides were then neutralized in $400 \mathrm{mM}$ Tris buffer (pH 4) for 5 min and stained with $\operatorname{EtBr}(20 \mu \mathrm{g} / \mathrm{mL})$. DNA migration was observed by using fluorescence microscope LEICA DMR (Wetzlar, Germany) and images were taken from approximately 10 fields of the each slide by using LEICA DC 300 camera. Image analysis system CometScore v1.5 (TriTek Corp., USA) was employed to determine the percentage of DNA in comet tail (\%DNA) and the tail moment $\left(\mathrm{M}_{\mathrm{t}}\right)$. These parameters were calculated as follows:

$$
\begin{gathered}
\% D N A t=\frac{I t}{I c} \times 100 \\
M t=\% D N A t \times L t
\end{gathered}
$$

where $I t$ is the total comet tail intensity, $I_{c}$ is the total comet intensity and $L t$ is the tail length.

\subsection{Statistical analysis}

The Comet assay was conducted on duplicate slides per concentration of extract of each hydrogel, as well as controls, with approximately 100 cells scored per slide. Normality of data was evaluated with the Kolmogorov-Smirnov test. The statistical difference between control and treated cells was analyzed with the nonparametric Mann-Whitney test using $\% \mathrm{DNA}_{\mathrm{t}}$ and $\mathrm{M}_{\mathrm{t}}$ values. The significance level was set at $\mathrm{p} \leq$ 0.01 . Multiple correlation analysis was performed in order to estimate the combined influence of independent variables (extract concentration, crosslinking density $\left(v_{e}\right)$ and swelling equilibrium $\left.\left(q_{e}\right)\right)$ on the dependent variable (\%DNAt). Regression analysis was employed to further define degree and type of relationship between independent and dependent variables, which showed significant correlation. Statistical analysis was performed using SPSS Statistics Version 17 for Windows. 


\section{Results and Discussion}

\subsection{Swelling properties}

The physical behavior of hydrogels is dependent on their equilibrium and dynamic swelling behavior in aqueous media. For application of hydrogels, swelling and shrinking kinetics are very important, e.g. in controlled release drug delivery systems, where the kinetics determine the rate of diffusion of the active component from the gel matrix and in gel extraction where the gel is swollen and shrunk several times ${ }^{48}$. Swelling kinetics of synthesized samples was determined by monitoring the swelling process in phophate buffer mimicking physiological conditions ( $\mathrm{pH} 7.4$ and 37 $\left.{ }^{\circ} \mathrm{C}\right)$. The equilibrium swelling degree $\left(q_{e}\right)$ values were in the range of $0.42-4.28$ (Figure 1). After the equilibrium swelling was reached all samples were kept in buffer solution for additional 10 days. Figure 1 shows that in that period $q_{e}$ values remained practically constant. Furthermore, at the end of this period, all samples had a soft consistency and exhibited a transparent and colorless appearance.

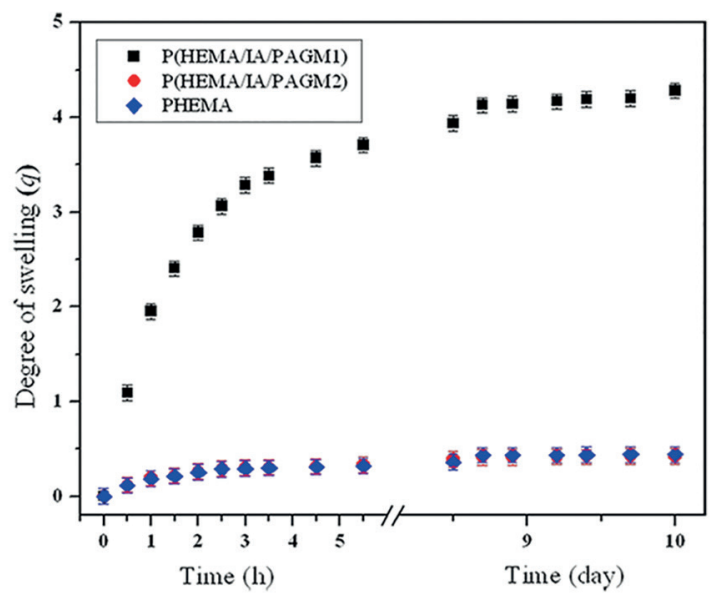

Figure 1: Swelling profiles and equilibrium degree of swelling $\left(q_{e}\right)$ of HEMA-based hydrogels in phosphate buffer (pH 7.4) at $37^{\circ} \mathrm{C}$.

The swelling properties depend on many factors such as network density, solvent nature and polymer-solvent interaction parameter ${ }^{4,49}$. P(HEMA/IA/PAGM1) hydrogel swells more than P(HEMA/IA/PAGM2) terpolymer and PHEMA homopolymer network. Terpolymer hydrogels contain different PAGM components, with pendent chains of different length which influenced the swelling process. The P(HEMA/IA/PAGM1) sample, with incorporated hydrophylic acrylate residue in the main chain and ethylene glycol pendant chains, reached substantially higher swelling degree than P(HEMA/IA/PAGM2) and PHEMA samples, with incorporated less hydrophylic methacrylate residues in the main chain and hydrophobic propylene glycol pendant chains in the case of P(HEMA/ IA/PAGM2) sample.
According to the potential biomedical application, the calculations of crosslinking densities were done for the results obtained in $\mathrm{pH} 7.4$, at $37^{\circ} \mathrm{C}$. The values of effective crosslinking densities for PHEMA, P(HEMA/IA/PAGM1) and P(HEMA/IA/PAGM2) were calculated as 48.18, 0.187 and $47.51 \mathrm{~mol} / \mathrm{dm}^{3}$, respectively. It is evident that in case of terpolymers (P(HEMA/IA/PAGM1) and P(HEMA/IA/ PAGM2)), effective crosslinking density depends very much on PAGM component, i.e. alkylene glycol pendant chains in the polymeric network. The $v_{e}$ values follow the expected trend in accordance with the hydrophilic character of the PAGM component and the crosslinking degree of the sample. The sample with the highest equilibrium degree of swelling (P(HEMA/IA/PAGM1)) has the lowest $v_{e}$ value. Due to the higher sensitivity of propylene glycol units in $\mathrm{P}(\mathrm{HEMA} / \mathrm{IA} / \mathrm{PAGM} 2)$ hydrogel to gamma radiation, in comparison to ethylene glycol units in P(HEMA/IA/ PAGM1) hydrogel, a higher crosslinking density in the case of P(HEMA/IA/PAGM2) hydrogel was obtained. Therefore, the crosslinking density values along with the hydrophobic/ hydrophilic character of monomer residues in hydrogel are in good accordance with their $q_{e}$ values.

\subsection{Comet assay}

Table 3 represents the results of Trypan Blue Dye Exclusion Method, employed to evaluate cytotoxicity concurrently with Comet assay.

Although a dose-dependent decrease in HeLa cell viability was observed, more than $70 \%$ of cells were viable after treatment with hydrogels' extracts, regardless the hydrogel type and extract concentration. According to ISO standard (ISO 10993-12), preparation of fluid extracts of the device materials is the most appropriate technique when there is a need to determine toxicity of possible chemical leachables, especially by Comet assay ${ }^{5,38}$. Because DNA damage is associated with cell death, evaluation of genotoxicity is only relevant at sub-cytotoxic concentrations of examined samples. It is crucial to evaluate cytotoxicity at the end of the exposure period and general approach is to exclude concentrations that decrease cell viability by more than $30 \%{ }^{50,51}$. Since the results of the Trypan Blue assay performed in this study show that cell viability, after exposure to the both concentrations of tested extracts, is higher than $70 \%$, none of the hydrogels' extracts can be considered cytotoxic to HeLa cells, and these extracts concentrations $(10 \%$ and $50 \%$ ) are suitable for further genotoxicity examination. Also, cell viability determined in this study was similar with the results obtained by using neutral red method in our previous characterization of these hydrogels ${ }^{43}$.

Figure 2 shows the representative images of HeLa cells after staining with EtBr in Comet assay.

The results of the Comet assay show that extracts of all tested hydrogels are capable to induce certain genotoxic 
Table 3. Cell viability and Comet assay data for HeLa cells exposed to the extracts of HEMA-based hydrogels for $24 \mathrm{~h}$.

\begin{tabular}{|c|c|c|c|}
\hline \multirow{2}{*}{ Treatment } & \multirow{2}{*}{ Cell viability (\%) } & \multicolumn{2}{|c|}{ DNA damage \pm S.E.M } \\
\hline & & Mean $\% \mathrm{DNA}_{\mathrm{t}}$ & Mean $\mathrm{M}_{\mathrm{t}}$ \\
\hline Untreated control & 94.8 & $3.19 \pm 0.63$ & $0.41 \pm 0.21$ \\
\hline \multicolumn{4}{|l|}{ PHEMA } \\
\hline $10 \%$ & 89.7 & $6.19 \pm 1.47$ & $0.76 \pm 0.62$ \\
\hline $50 \%$ & 79.4 & $11.03 \pm 1.39^{*}$ & $1.59 \pm 0.53 *$ \\
\hline \multicolumn{4}{|c|}{ P(HEMA/IA/PAGM1) } \\
\hline $10 \%$ & 88.1 & $7.47 \pm 1.8$ & $1.53 \pm 0.42$ \\
\hline $50 \%$ & 76.6 & $25.39 \pm 4.62 *$ & $8.78 \pm 1.35^{*}$ \\
\hline \multicolumn{4}{|c|}{ P(HEMA/IA/PAGM2) } \\
\hline $10 \%$ & 87.8 & $6.57 \pm 0.94$ & $0.71 \pm 0.26$ \\
\hline $50 \%$ & 74.7 & $23.82 \pm 2.15^{*}$ & $4.63 \pm 0.85^{*}$ \\
\hline Positive control $^{\mathrm{a}}$ & 69.5 & $21.11 \pm 1.85^{*}$ & $8.59 \pm 1.71 *$ \\
\hline
\end{tabular}

a Positive control agent: $200 \mu \mathrm{M} \mathrm{H}_{2} \mathrm{O}_{2}$; * Denotes a significant difference from the untreated control $(\mathrm{p} \leq 0.01)$.
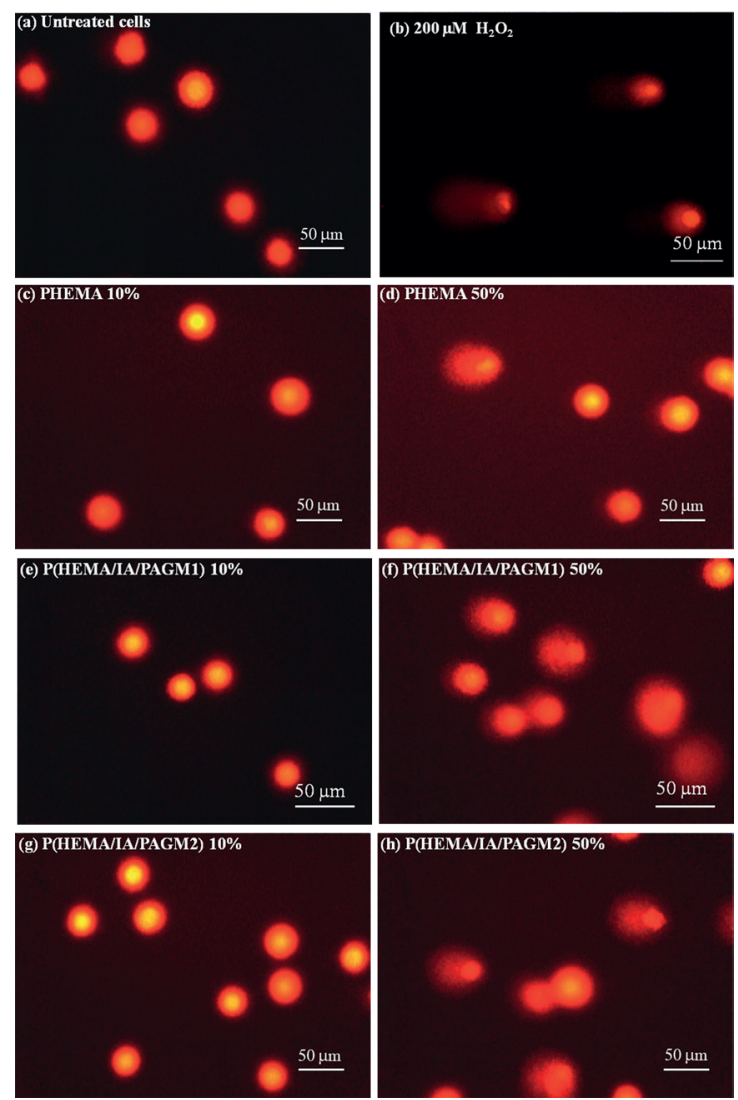

Figure 2: Representative images of HeLa cells in Comet assay; untreated cells (a), cells treated with $200 \mu \mathrm{M} \mathrm{H}_{2} \mathrm{O}_{2}$ (b) and cells treated with two concentrations $(10 \%$ and $50 \%)$ of PHEMA (c, d), P(HEMA/IA/PAGM1) (e, f) and P(HEMA/IA/PAGM2) $(\mathrm{g}, \mathrm{h})$ hydrogels' extracts. Magnification $\times 400$.

effects, as measured by $\% \mathrm{DNA}_{\mathrm{t}}$ and $\mathrm{M}_{\mathrm{t}}$ parameters (Table 3, Figure 2). Extracts of tested HEMA-based hydrogels in concentration of $10 \%$ induced no significant increase in $\% \mathrm{DNA}_{t}$ and $\mathrm{M}_{\mathrm{t}}$ compared with untreated cells. Significant augmentation of DNA migration $(\mathrm{p}<0.01)$ was evident only after treatment of HeLa cells with higher extract concentration (50\%). Extracts of PHEMA, P(HEMA/IA/PAGM1) and $\mathrm{P}(\mathrm{HEMA} / \mathrm{IA} / \mathrm{PAGM} 2)$ hydrogels in concentration of $50 \%$ induced $1.8(\mathrm{p} \leq 0.05), 3.4(\mathrm{p} \leq 0.01)$ and $3.6(\mathrm{p} \leq 0.01)$ times higher $\% \mathrm{DNA}_{\mathrm{t}}$ compared with $\% \mathrm{DNA}_{t}$ induced by lower concentration (10\%) of the same extracts. Also, higher extracts' concentrations induced up to 3.6 times higher $\mathrm{M}_{t}$ than same extracts of lower concentration. $\mathrm{M}_{\mathrm{t}}$ parameter is also presented as Tukey box plot diagram (Figure 3). The outliners that can be seen in untreated control as well as in treated cells, are probably the cells that underwent spontaneous apoptosis/necrosis events ${ }^{29}$ and were not included in the analysis.

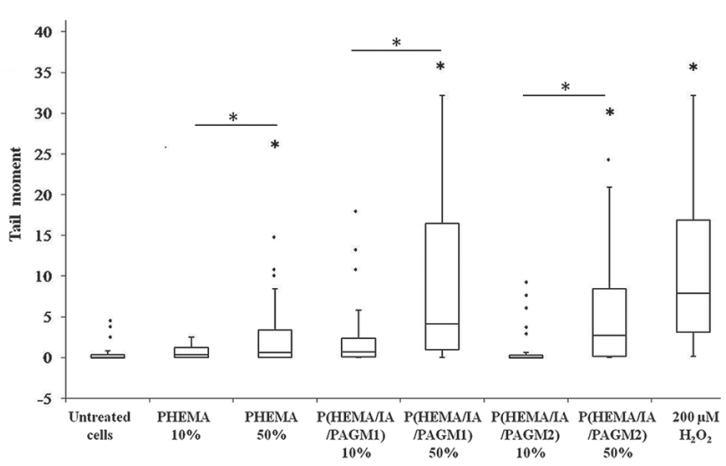

Figure 3: Tukey box plot diagram for tail moment parameter of HeLa cells treated with $10 \%$ and $50 \%$ extracts of HEMA-based hydrogels, $200 \mu \mathrm{M} \mathrm{H}_{2} \mathrm{O}_{2}$ as positive control and untreated cells. Whiskers extend to the 1.5 box heights. If minimum and maximum values are out of this range, then they are shown as outliners (dots above boxes). *Denotes a statistically significant differences between concentrations of extracts and compared with untreated control $(\mathrm{p} \leq 0.01)$.

The extent of DNA damage depends on extract concentration as well as on properties of hydrogel such as crosslinking density $\left(v_{e}\right)$ and swelling equilibrium $\left(q_{e}\right)$. In order to analyze the impact of each independent variable 
(extract concentration, $v_{e}$ and $q_{e}$ ) on the dependent variable $\left(\% \mathrm{DNA}_{\mathrm{t}}\right)$, we performed multiple correlation analysis.

As presented in Figure 4a, extract concentration showed the strongest positive impact on genotoxicity as determined by correlation coefficient $(0.82)$. We further analized the relationship between extract concentration and genotoxicity by employing regression analysis. As can be seen in Figure $4 \mathrm{~b}$, coefficient of determination $\left(\mathrm{R}^{2}\right)$ equals 0.68 , which means that $68 \%$ of the variation in genotoxicity is explained by the extract concentration. According to the coefficients, the equation of regression line is:

$$
\mathrm{y}=3.41+0.33 \mathrm{x}
$$

In other words, for each unit increase in extract concentration (x), genotoxicity (y) increases with 0.33 units. This could be valuable information when there is a need to predict the genotoxic effect of different concentrations of extract.

The $\% \mathrm{DNA}_{t}$ values of the cells treated with the same concentration $(50 \%)$ of extracts of tested hydrogels were compared. The results indicate that genotoxic potential increases in this order: PHEMA $<$ P(HEMA/IA/PAGM2) $<$ P(HEMA/IA/ PAGM1). In other words, extracts of P(HEMA/IA/PAGM1) and P(HEMA/IA/PAGM2) hydrogels induced about 2.2 $(p \leq 0.01)$ times higher \%DNA than PHEMA hydrogel's extract. The extent of DNA damage induced by P(HEMA/ IA/PAGM1) is about $1.1(\mathrm{p} \leq 0.05)$ time higher than in the case of P(HEMA/IA/PAGM2) hydrogels' extract. Therefore, it is obvious that properties of hydrogel such as its degree of crosslinking, swelling equilibrium and genotoxic potential, are related. Impact of these independent variables on genotoxicity was also tested by employing multiple correlation analysis (Figure 4a). Crosslinking density of the hydrogel and its swelling equilibrium are in almost perfect negative correlation - increasing of crosslinking density reduces the swelling equilibrium. These two variables have opposite influence on genotoxicity $\left(\% \mathrm{DNA}_{t}\right)$ - increasing of crosslinking density reduces while increasing of swelling equilibrium increases the genotoxic effect of hydrogel extracts. However, the influence of crosslinking density and swelling equilibrium on overall genotoxicity is relatively weak as measured by correlation coefficients $(\approx 0.26$, Figure $4 \mathrm{a})$. PHEMA homopolymer and P(HEMA/IA/PAGM2) terpolymer have higher effective crosslinking density $\left(v_{\mathrm{e}}\right)$, lower equilibrium degree of swelling $\left(q_{e}\right)$, and show less pronounced genotoxic effect than P(HEMA/IA/PAGM1) terpolymer. The generally accepted property of highly crosslinked polymers is that they are more resistant to degradative processes and elution of unreacted components, based on more limited space and pathways available for solvent molecules to diffuse within (a)

\begin{tabular}{cccc} 
& \multicolumn{1}{c}{$\begin{array}{c}\text { Extract } \\
\text { concentration }\end{array}$} & $\begin{array}{c}\text { Crosslinking } \\
\text { density }\left(\mathrm{v}_{\mathrm{e}}\right)\end{array}$ & $\begin{array}{c}\text { Swelling } \\
\text { equilibrium } \\
\left(\mathrm{q}_{\mathrm{e}}\right)\end{array}$ \\
\cline { 2 - 4 } $\begin{array}{c}\text { Extract } \\
\text { concentration }\end{array}$ & 1 & - & - \\
\hline $\begin{array}{c}\text { Crosslinking } \\
\text { density }\left(\mathrm{v}_{\mathrm{e}}\right)\end{array}$ & 0 & 1 & - \\
\hline $\begin{array}{c}\text { Swelling } \\
\text { equilibrium } \\
\left(\mathrm{q}_{\mathrm{e}}\right)\end{array}$ & 0 & $\mathbf{- 0 . 9 9 9 7}$ & 1 \\
\hline $\begin{array}{c}\text { Genotoxicity } \\
(\% \mathrm{DNA})\end{array}$ & $\mathbf{0 . 8 2}$ & $\mathbf{0 . 2 7}$ & $\mathbf{0 . 2 6}$ \\
\hline
\end{tabular}

(b)

Multiple R

0.82

$R^{2}$

0.68

Significance $F$

0.04

Coefficients

Genotoxicity (y)

Extract concentration $(x)$
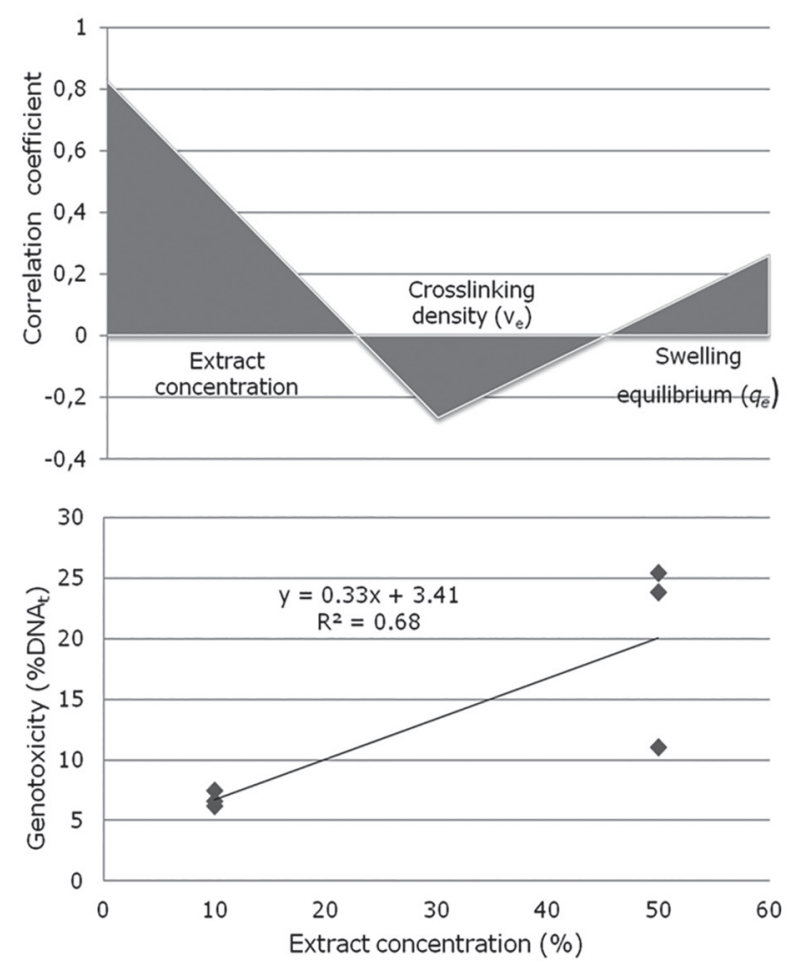

Figure 4: (a) Multiple correlation analysis employed to determine the strength and direction of the association between the independent variables (extract concentration, crosslinking density $\left(v_{e}\right)$ and swelling equilibrium $\left(q_{e}\right)$ ) and the one dependent variable (\%DNAt). Correlation coefficient ranges between -1 to +1 , and quantifies the stenght (the closer coefficient is to 1 , the stronger linear association is) and the direction (positive or negative) of the association. (b) Regression analysis of the relationship between extract concentration and genotoxicity, based on significant correlation among these two variables. 
structure $^{13,52,53}$. The elution of unreacted components from hydrogels is influenced by several factors including the chemical composition of components in hydrogel synthesis, the conversion during polymerization reaction and the degree of crosslinking of the polymeric network ${ }^{13}$. Due to the lowest degree of crosslinking, extract of P(HEMA/IA/ PAGM1), which showed the highest level of genotoxicity, probably contains more unreacted components comparing with extracts of PHEMA and P(HEMA/IA/PAGM2) samples. In the case of tested hydrogels, these unreacted monomers are IA, methacrylates HEMA and PAGM2, and acrylate PAGM1. It is well known that unreacted monomers in hydrogels can cause the living tissue damage ${ }^{13,54}$. Itaconic acid is a component of natural origin and it is supposed that will not induce genotoxicity. (Meth)acrylate monomers are reported in the literature to exhibit genotoxic effects ${ }^{24-30}$. Furthermore, Dearfield et al. ${ }^{55}$ showed that acrylates are generally more potent to induce mutations, abberations and micronuclei than methacrylates, although this appears to be structure-related (dependent upon number of functional vinyl groups and the length of oxyethylene chains). PAGM1 has functional vinyl group and longer oxyethylene chain than PAGM2 and this structural difference may be responsible for its more potent genotoxic effect detected in Comet assay. However, this study is the first step in biocompatibility assessment of these novel HEMA-based hydrogels and it is early to comment on the mechanisms underlying the increased DNA migration observed in the alkaline version of Comet assay.

\section{Conclusion}

Swelling studies confirmed that hydrogels based on 2-hydroxyethyl methacrylate, poly(alkylene glycol) (meth)acrylates and itaconic acid swell in phosphate buffer but maintain physical integrity and have soft and rubbery consistency even when the swelling experiments were conducted for a long time after the equilibrium state was reached. The results of the Comet assay showed that extracts of all tested hydrogels are capable to induce certain genotoxic effects, which depended on chemical composition, extract concentration as well as on degree of crosslinking of examined hydrogels. Future research would be directed toward optimization of the synthesis of these novel HEMA-based hydrogels in order to obtain hydrogels that are not genotoxic at all and, as such, may have application in clinical practice.

\section{Acknowledgments}

This work was supported by the Ministry of Education, Science and Technological Development of the Republic of Serbia under Grant [III 41017] and Grant [OI 172062].

\section{Conflict of interests}

Authors declare that they have no conflict of interests.

\section{References}

1. Chaterji S, Kwon IK, Park K. Smart polymeric gels: Redefining the limits of biomedical devices. Progress in Polymer Science. 2007;32(8-9):1083-1122.

2. Urban MW. Stratification, stimuli-responsiveness, self-healing, and signaling in polymer networks. Progress in Polymer Science. 2009;34(8):679-687.

3. Drury JL, Mooney DJ. Hydrogels for tissue engineering: scaffold design variables and applications. Biomaterials. 2003;24(24):4337-4351.

4. Zhu J, Marchant RE. Design properties of hydrogel tissueengineering scaffolds. Expert Review of Medical Devices. 2011;8(5):607-626.

5. Devine DM, Devery SM, Lyons JG, Geever LM, Kennedy JE, Higginbotham CL. Multifunctional polyvinylpyrrolidinonepolyacrylic acid copolymer hydrogels for biomedical applications. International Journal of Pharmaceutics. 2006;326(1-2):50-59.

6. Caló E, Khutoryanskiy VV. Biomedical applications of hydrogels: A review of patents and commercial products. European Polymer Journal. 2015;65:252-267.

7. Yates DW, Hadfield JM. Clinical experience with a new hydrogel wound dressing. Injury. 1984;16(1):23-24.

8. Maldonado-Codina C, Efron N. Hydrogel lenses - Materials and Manufacture: A Review. Optometry in Practice. 2003;4:101-115.

9. Young CD, Wu JR, Tsou TL. Fabrication and characteristics of polyHEMA artificial skin with improved tensile properties. Journal of Membrane Science. 1998;146(1):83-93.

10. Çetin D, Kahraman AS, Gümüşderelioğlu M. Novel scaffolds based on poly(2-hydroxyethyl methacrylate) superporous hydrogels for bone tissue engineering. Journal of Biomaterials Science. Polymer Edition. 2011;22(9):1157-78.

11. Costa VC, Costa HS, Vasconcelos WL, Pereira MM, Oréfice RL, Mansur HS. Preparation of hybrid biomaterials for bone tissue engineering. Materials Research. 2007;10(1):21-26.

12. Keeney M, Lai JH, Yang F. Recent progress in cartilage tissue engineering. Current Opinion in Biotechnology. 2011;22(5):734-740.

13. Bakopoulou A, Papadopoulos T, Garefis P. Molecular Toxicology of Substances Released from Resin-Based Dental Restorative Materials. International Journal of Molecular Sciences. 2009;10(9):3861-3899.

14. Tomić SLj, Dimitrijević SI, Marinković AD, Najman S, Filipović JM. Synthesis and characterization of poly(2hydroxyethylmethacrylate/itaconic acid) copolymeric hydrogels. Polymer Bulletin. 2009;63(6):837-851.

15. Fathi M, Entezami AA, Arami S, Rashidi MR. Preparation of $\mathrm{N}$-isopropylacrylamide/itaconic acid magnetic nanohydrogels by modified starch as a crosslinker for anticancer drug carriers. International Journal of Polymeric Materials and Polymeric Biomaterials. 2015;64(10):541-549. 
16. Brahim S, Narinesingh D, Giuseppi-Elie A. Release characteristics of novel $\mathrm{pH}$-sensitive p(HEMA-DMAEMA) hydrogels containing 3-(trimethoxy-silyl) propyl methacrylate. Biomacromolecules. 2003;4(5):1224-1231.

17. Ozay O. Synthesis and characterization of novel $\mathrm{pH}$-responsive poly(2-hydroxylethyl methacrylate-co- $N$-allylsuccinamic acid) hydrogels for drug delivery. Journal of Applied Polymer Science. 2014;131(1):39660. doi: 10.1002/app.39660.

18. García DM, Escobar JL, NoaY, Bada N, Hernáez E, Katime I. Timolol maleate release from $\mathrm{pH}$-sensible poly (2-hydroxyethyl methacrylate-co-methacrylic acid) hydrogels. European Polymer Journal. 2004;40(8):1683-1690.

19. Johnson BD, Beebe DJ, Crone WC. Effects of swelling on the mechanical properties of a $\mathrm{pH}$-sensitive hydrogel for use in microfluidic devices. Materials Science and Engineering: $C$. 2004;24(4):575-581.

20. Tomić SLj, Mićić MM, Dobić SN, Filipović JM, Suljovrujić EH. Smart poly(2-hydroxyethyl methacrylate/itaconic acid) hydrogels for biomedical application. Radiation Physics and Chemistry. 2010;79(5):643-649.

21. Nasr FH, Khoee S, Dehghan MM, Chaleshtori SS, Shafiee A. Preparation and evaluation of contact lenses embedded with polycaprolactone-based nanoparticles for ocular drug delivery. Biomacromolecules. 2016;17(2):485-495.

22. Omidian H, Park K, Kandalam U, Rocca J. Swelling and mechanical properties of modified HEMA-based superporous hydrogels. Journal of Bioactive and Compatible Polymers. 2010;25(5):483-497.

23. Kirf D, Higginbotham CL, Rowan NJ, Devery SM. Cyto- and genotoxicological assessment and functional characterization of $\mathrm{N}$-vinyl-2-pyrrolidone-acrylic acid-based copolymeric hydrogels with potential for future use in wound healing applications. Biomedical Materials (Bristol, England). 2010;5(3):35002.

24. Chang HH, Guo MK, Kasten FH, Chang MC, Huang GF, Wang YL, et al. Stimulation of glutathione depletion, ROS production and cell cycle arrest of dental pulp cells and gingival epithelial cells by HEMA. Biomaterials. 2005;26(7):745-753.

25. Becher R, Kopperud HM, Al RH, Samuelsen JT, Morisbak E, Dahlman HJ, et al. Pattern of cell death after in vitro exposure to GDMA, TEGDMA, HEMA and two compomer extracts. Dental Materials. 2006;22(7):630-640.

26. Spagnuolo G, D’Antò V, Cosentino C, Schmalz G, Schweikl $\mathrm{H}$, Rengo S. Effect of N-acetyl-L-cysteine on ROS production and cell death caused by HEMA in human primary gingival fibroblasts. Biomaterials. 2006;27(9):1803-1809.

27. Toy E, Yuksel S, Ozturk F, Karatas OH, Yalcin M. Evaluation of the genotoxicity and cytotoxicity in the buccal epithelial cells of patients undergoing orthodontic treatment with three light-cured bonding composites by using micronucleus testing. Korean Journal of Orthodontics. 2014;44(3):128-135.

29. Lee DH, Lim BS, Lee YK, Ahn SJ, Yang HC. Involvement of oxidative stress in mutagenicity and apoptosis caused by dental resin monomers in cell cultures. Dental Materials. 2006;22(12):1086-1092.
29. Schweikl H, Hartmann A, Hiller KA, Spagnuolo G, Bolay C, Brockhoff G, Schmalz G. Inhibition of TEGDMA and HEMAinduced genotoxicity and cell cycle arrest by $\mathrm{N}$-acetylcysteine. Dental Materials. 2007;23(6):688-695.

30. Kleinsasser NH, Wallner BC, Harréus UA, Kleinjung T, Folwaczny M, Hickel R, et al. Genotoxicity and cytotoxicity of dental materials in human lymphocytes as assessed by the single cell microgel electrophoresis (comet) assay. Journal of Dentistry. 2004;32(3):229-234.

31. Kleinsasser NH, Schmid K, Sassen AW, Harreus UA, Staudenmajer $\mathrm{R}$, Folwaczny M, et al. Cytotoxic and genotoxic effects of resin monomers in human salivary gland tissue and lymphocytes as assessed by the single cell microgel electrophoresis (comet) assay. Biomaterials. 2006;27(9):1762-1770.

32. Pawlowska E, Poplawski T, Ksiazek D, Szczepanska J, Blasiak J. Genotoxicity and cytotoxicity of 2-hydroxyethyl methacrylate. Mutation Research. 2010;696(2):122-129.

33. Ginzkey C, Zinnitsch S, Steussloff G, Koehler C, Hackenberg S, Hagen R, et al. Assessment of HEMA and TEGDMA induced DNA damage by multiple genotoxicological endpoints in human lymphocytes. Dental Materials. 2015;31(8):865-876.

34. Szczepanska J, Poplawski T, Synowiec E, Pawlowska E, Chojnacki CJ, Chojnacki J, et al. 2-hydroxylethyl methacrylate (HEMA), a tooth restoration component, exerts its genotoxic effects in human gingival fibroblasts trough methacrylic acid, an immediate product of its degradation. Molecular Biology Reports. 2012;39(2):1561-1574.

35. Thankam FG, Muthu J. Infiltration and sustenance of viability of cells by amphiphilic biosynthetic biodegradable hydrogels. Journal of Materials Science: Materials in Medicine. 2014;25(8):1953-1965.

36. Samuelsen JT, Holme JA, Becher R, Karlsson S, Morisbak E, Dahl JE. HEMA reduces cell proliferation and induces apoptosis in vitro. Dental Materials. 2008;24(1):134-140.

37. Liao W, McNutt MA, Zhu WG. The comet assay: a sensitive method for detecting DNA damage in individual cells. Methods. 2009;48(1):46-53.

38. Tice RR, Agurell E, Anderson D, Burlinson B, Hartmann A, Kobayashi H, et al. Single cell gel/comet assay: guidelines for in vitro and in vivo genetic toxicology testing. Environmental and Molecular Mutagenesis. 2000;35(3):206-221.

39. Olive PL, Banáth PJ. The comet assay: a method to measure DNA damage in individual cells. Nature Protocols. 2006;1(1):23-29.

40. Collins AR, Dobson VL, Dusinská M, Kennedy G, Štětina R. The comet assay: what can it really tell us? Mutation Research/ Fundamental and Molecular Mechanisms of Mutagenesis. 1997;375(2):183-193.

41. Collins AR, Oscoz AA, Brunborg G, Gaivão I, Giovannelli L, Kruszewski M, et al. The comet assay: topical issues. Mutagenesis. 2008;23(3):143-151.

42. Thankam Finosh G, Jayabalan M. Reactive oxygen speciesControl and management using amphiphilic biosynthetic hydrogels for cardiac applications. Advances in Bioscience and Biotechnology. 2013;4(12):1134-1146. 
43. Tomić SLj, Babić MM, Antić KM, Vuković JSJ, Malešić NB, Filipović JM. pH sensitive hydrogels based on (meth)acrylates and itaconic acid. Macromolecular Research. 2014;22(11):1203-1213.

44. Bell CL, Peppas NA. Measurement of the swelling force in ionic polymer networks. III. Swelling force of interpolymer complexes. Journal of Controlled Release. 1995;37(3):277-280.

45. Peppas NA. Analysis of Fickian and non-Fickian drug release from polymers. Pharmaceutica Acta Helvetiae. 1985;60(4):110-111.

46. Çaykara T, Doğmuş M, Kantoğlu Ö. Network structure and swelling-shrinking behaviours of $\mathrm{pH}$-sensitive poly(acrylamideco-itaconic acid) hydrogels. Journal of Polymer Science Part B Polymer Physics. 2004;42(13):2586-2594.

47. Dhawan A, Bajpayee M, Pandey AK, Parmar D. Protocol for the single cell gel electrophoresis/comet assay for rapid genotoxicity assessment. Lucknow: Industrial Toxicology Research Centre; 2003. p 1-10. Available from: <http://www. cometassayindia.org/protocol\%20for $\% 20$ comet $\% 20$ assay.pdf $>$. Access in: 30/7/2016.

48. Andersson M, Axelsson A, Zacch G. Swelling kinetics of poly( $N$-isopropylacrylamide) gel. Journal of Controlled Release. 1998;50(1-3):273-281.
49. Hoffman AS. Hydrogels for biomedical applications. Advanced Drug Delivery Reviews. 2002;54(1):3-12.

50. Henderson L, Wolfreys A, Fedyk J, Bourner C, Windebank S. The ability of the Comet assay to discriminate between genotoxins and cytotoxins. Mutagenesis. 1998;13(1):89-94.

51. Anderson D, Yu TW, McGregor DB. Comet assay responses as indicators of carcinogenic exposure. Mutagenesis. 1998;13(6):539-555.

52. Krongauz VV. Diffusion in polymers dependence on crosslink density. Journal of Thermal Analysis and Calorimetry. 2010;102(2):435-445.

53. Wu Y, Joseph S, Aluru NR. Effect of cross-linking on the diffusion of water, ions, and small molecules in hydrogels. The Journal of Physical Chemistry B. 2009;113(11):3512-3520.

54. Das N. Preparation methods and properties of hydrogel: a review. International Journal of Pharmacy and Pharmaceutical Sciences. 2013;5(3):112-117.

55. Dearfield KL, Milis CS, Harrington-Brock K, Doerr CL, Moore MM. Analysis of the genotoxicity of nine acrylate/methacrylate compounds in L5178Y mouse lymphoma cells. Mutagenesis. 1989;4(5):381-393. 